\title{
Pengembangan SSP Biologi Domain Kreativitas untuk Meningkatkan Karakter Kreatif, Tanggung Jawab dan Prestasi Belajar Siswa
}

\author{
Ary Kusmawati \\ SMA Negeri 9 Pontianak. Jalan Tanjung Raya 2, Saigon, Kota Pontianak, 78243, Indonesia \\ Email: farras_da@yahoo.co.id
}

Received: 17 April 2017; Revised: 20 April 2017; Accepted: 19 June 2017

\begin{abstract}
Abstrak
Tujuan penelitian ini untuk: (1) mengembangkan SSP Biologi berbasis domain kreativitas dalam mengembangkan karakter kreatif dan tanggung jawab pada diri siswa; (2) mengetahui kualitas SSP Biologi berbasis domain kreativitas untuk meningkatkan karakter kreatif dan tanggung jawab pada siswa; (3) mengetahui SSP Biologi berbasis domain kreativitas yang dihasilkan mampu meningkatkan karakter kreatif dan tanggung jawab serta prestasi hasil belajar siswa. Metode yang digunakan dalam penelitian ini adalah Research and Development (R \& D). Subjek uji coba dalam penelitian ini adalah kelas XI IPA 3 (sebagai kelas kontrol) dan XI IPA 5 (sebagai kelas treatmen) yang masing-masing kelas terdiri atas 30 siswa. Pengumpulan data dilakukan dengan menggunakan pedoman wawancara, lembar validasi SSP, angket, lembar observasi, dan tes yang terdiri atas pretest dan posttest. Hasil penelitian dalam pengembangan perangkat SSP Biologi domain kreativitas untuk meningkatkan karakter kreatif dan tanggung jawab pada siswa yang terdiri atas pengembangan Silabus, RPP, Materi ajar, LKS, penilaian tes belajar siswa sudah valid dan layak digunakan karena memiliki kategori sangat baik. Perangkat SSP Biologi domain kreativitas untuk meningkatkan karakter kreatif dan tanggung jawab mampu meningkatkan karakter kreatif dan tanggung jawab pada siswa dengan katagori sangat baik.
\end{abstract}

Kata Kunci: SSP, kreativitas, karakter, kreatif, tanggung jawab

\section{Developing Creativity Domain Biology SSP to Improve Students' Creative Character, Responsibility, and Learning Achievement}

\begin{abstract}
This study aims to: (1) develop creativity-domain-based biology SSP to improve the creative and responsibility character in students. (2) reveal the quality the creativity-domain-based biology SSP to improve the creativity and responsibility characters of students.(3) knowing quality developing the creativity-domain-based biology SSP to improve the creativity, responsibility character and the resulting study of student. The method in this study was Research and Development $(R \& D)$ consisting of 10 primary steps developed by Borg \& Gall; this study, however, used only steps 1 to 7, i.e.a preliminary study, planning, SSP draft construction and validation, a small-scale try out, evaluation and revision, a largescale try out, and evaluation and final revision. The try out subjects were grade XI IPA students, consisting of 15 Grade XI IPA 1 students for the small-scale try out and 30 Grade XI IPA 3 students as the control class, 30 Grade student of XI IPA 5 as the experimental class. The data were collected by means of an interview guide, a kit validation sheet, a questionnaire, an observation sheet, and tests consisting of a pretest and post-test. Feedback and suggestion for the developed SSP in the small-scale try out stage were used as the basis for the SSP revision in the subsequent tryout. The result of study consisting of the development of syllabus, lesson plant, teaching materials, worksheets, student assessment test, according to the research is valid and fit for use because it is in a very good category. The SSP device creativitydomain-based biology to enhance the creativity and responsibility characters can improve creativity and responsibility characters of the students, which is a very good character.
\end{abstract}

Keywords: SSP, creativity, character, creative, responsibility

How to Cite: Kusmawati, A. (2017). Pengembangan SSP biologi domain kreativitas untuk meningkatkan karakter kreatif, tanggung jawab dan prestasi belajar siswa. Jurnal Inovasi Pendidikan IPA, 3(1), 12-21. doi:http://dx.doi.org/10.21831/jipi.v3i1.13683

Permalink/DOI: http://dx.doi.org/10.21831/jipi.v3i1.13683 


\section{Jurnal Inovasi Pendidikan IPA, 3 (1), 2017 - 13}

Ary Kusmawati

\section{PENDAHULUAN}

Pembelajaran Biologi tidak hanya menekankan aspek pengetahuan saja namun lebih menekankan pada pengalaman atau pengamatan secara langsung di lingkungan dengan mengembangkan keterampilan proses, kreativitas, sikap, tingkah laku, terapan dan tanggung jawab. Pengamatan dan pengalaman langsung di lingkungan diharapkan siswa mampu memiliki kompetensi yang dimiliki dalam memecahan suatu permasalah yang terjadi dalam kehidupan sehari-hari.

Hal ini di harapkan sesuai dengan tujuan sistem pendidikan nasional untuk menciptakan generasi penerus bangsa yang memiliki karakter religius, berakhlak mulia, cendekia, mandiri dan demokratis. Keberhasilan suatu pendidikan ditunjukkan dengan kemampuan masyarakat dalam mengatasi dan menghadapi berbagai permasalahan yang terjadi dengan membentuk karakter kehidupan masyarakat dan bangsa yang lebih baik di masa depan. Pendidikan merupakan suatu tindakan atau pengalaman yang bukan hanya berpengaruh terhadap pertumbuhan atau perkembangan jiwa (mind) dan kemampuan fisik (physical ability) individu tetapi juga di peruntukan untuk pembentukan watak (character) dikenal dengan pembentukan karakter (Siswoyo, 2007, p. 12).

Istilah karakter berkaitan dengan istilah etika, akhlak, nilai dan berkaitan dengan kekuatan moral, berkonotasi positif bukan netral (Anonim, 2010, p.7). Karakter berasal dari bahasa Yunani yaitu "charassein" yang berarti membuat tajam, membuat dalam (Bernice, 2010, p. 2). Karakter menurut Pusat Penelitian Bahasa berarti bawaan, hati, jiwa, kepribadian, budi pekerti, perilaku, personalitas, sifat, tabiat, temperamen dan watak.

Menurut Anonim (2011, p.35), menyatakan ada enam pilar dari karakter, yakni kejujuran (trustworthiness), respek (respect), tanggung jawab (responsibility), keadilan (fairness), kepedulian (caring), dan kewarganegaraan (citizenship). Namun, pilar karakter ini bisa berbeda antara yang berlaku di suatu masyarakat dengan masyarakat lainnya sesuai dengan nilai-nilai yang dianggap baik. Terdapat tiga komponen karakter yang baik (components of good character) yaitu moral knowing (pengetahuan tentang moral), moral feeling atau perasaan (penguatan emosi) tentang moral, dan moral action atau perbuatan bermoral (Lickona, 1991).

Pendidikan karakter dimaknai sebagai pendidikan nilai, budi pekerti, pendidikan moral dan pendidikan akhlak. Pendidikan karakter bertujuan mengembangkan kemampuan peserta didik untuk memberikan keputusan baik buruk, memelihara apa yang baik dan mewujudkan dalam kehidupan sehari-hari dengan sepenuh hati (Zuchdi et al., 2009, p. 2).

Karakteristik pembelajaran biologi tidak hanya ditunjukan oleh kumpulan fakta tetapi metode ilmiah dan sikap ilmiah yang dapat menjadikan kebiasaan sikap terhadap peserta didik. Biologi merupakan salah satu objek penunjang dalam meningkatkan pemahaman dan penghayatan siswa secara komprehensif.

Pada saat ini sikap, proses dan aplikasi pada pembelajaran Biologi masih dominan pada proses learning to know dan lerning to do, kurang mengembangkan proses learning to be dan learning to live together.

Pembelajaran Biologi perlu dirancang, didesain sehingga memberikan ruang kepada peserta didik untuk menggunakan seluruh inderanya untuk menemukan fakta-fakta, membangun konsep dengan keterampilan proses dan karakter peserta didik. Keefektivitasan metode pembelajaran juga ditentukan oleh karakterisrik maupun bakat siswa, materi/bahan ajar, sistem pembelajaran serta tipe guru mengajar. Menurut Usman (2006), belajar efektif harus mulai dengan pengalaman langsung atau pengalaman konkret dan menuju kepada pengalaman yang lebih abstrak.

Guru merupakan faktor yang strategis dalam aktivitas suatu pembelajaran. Sebagai agen pembelajaran, guru dituntut memiliki seperangkat kompetensi, yang meliputi kompetensi kepribadian, pedagogis, professional, dan sosial. Kompetensi pedagogis mengisyaratkan bahwa seorang guru dituntut memiliki kemampuan manajerial dalam hal mengelola kegiatan pembelajaran, yang menyangkut perencanaan (planning), pengorganisasian (organizing), kepemimpinan (leadership), dan pengawasan (controlling) agar dapat tercapai tujuan pendidikan secara efektif dan efisien.

Peningkatkan kemampuan guru dalam proses pembelajaran siswa agar tercermin pendidikan yang berkarakter melalui pembelajaran Biologi, maka salah satu cara yang dapat dikembangakan adalah dengan menggunakan perangkat pembelajaran Biologi berbasis pendidikan karakter domain kreativitas sehingga terbentuk karakter kreatif dan tanggung jawab yang diinginkan.

Kreativitas dapat didefinisikan sebagai aktivitas kognitif atau proses berpikir untuk 


\section{Jurnal Inovasi Pendidikan IPA, 3 (1), 2017 - 14}

Ary Kusmawati

menghasilkan gagasan-gagasan yang baru dan berguna (Munandar, 2002, p. 8). Kreativitas adalah kemampuan memulai ide, melihat hubungan yang baru atau tak diduga sebelumnya, kemampuan memformulasikan konsep yang tak sekedar menghafal, menciptakan jawaban baru untuk soal-soal yang ada dan mendapatkan pertanyaan baru yang perlu dijawab (Musbikin, 2006, p. 6).

Menurut Seifert (2008, p. 157), ada empat ciri kreativitas. Pertama adalah kefasihan, kemampuan menghasilkan aneka respon, tanpa interupsi eksternal terhadap sebuah stimulus atau masalah. Kedua adalah fleksibilitas, kemampuan untuk mendekati sebuah masalah dari berbagai sudut tertentu. Ketiga adalah orisinalitas, kemampuan menciptakan sebuah respon unik atau tidak lazim. Keempat adalah keluasan, kemampuan menambahkan kekayaan atau aneka detail terhadap sebuah respon.

Sikap dan perilaku tanggung jawab menurut Zuriah (2011, p. 83), merupakan sikap yang berani menanggung segala akibat dari perbuatan yang telah dilakukannya. Dengan rasa tanggung jawab yang dimiliknya ia selalu berusaha mengambil keputusan yang bisa dipertanggungjawabkan, baik dihadapan sesama manusia maupun di hadapan Allah (Munir, 2010, p. 92). Tanggung jawab akan tumbuh jika anak memiliki visi yang kuat.

Subjek Spesifik Pedagogi (SSP) memiliki persamaan arti dengan Pedagogy Contents Knowledge (PCK). Shulman dalam Koehler \& Mishra (2009) menyebutkan bahwa PCK terletak pada perpaduan antara konten dan pendagogi. Perpaduan tersebut mengubah konten menjadi bentuk yang sangat mudah digunakan untuk pembelajaran. SSP merupakan pengetahuan yang diterapkan untuk proses pembelajaran yang lebih spesifik tentang transformasi materi yang digunakan untuk bahan pembelajaran.

SSP merupakan pengemasan bidang studi menjadi perangkat pembelajaran komprehensif mencakup standar kompetensi, kompetensi dasar, materi, strategi, metode, dan media, serta evaluasi (instrumen penilaian hasil belajar). SSP meliputi: Silabus, Rencana Pelaksanaan Pembelajaran (RPP), Materi, Lembar Kegiatan Siswa dan Butir Soal (posttest dan tes kinerja). Perangkat pembelajaran yang dikembangkan ditelaah dengan lembar telaah yang formatnya diadaptasi dari BSNP yaitu dengan menuliskan ada tidaknya tiap ranah yang diharapkan dari tiap perangkat.Semua perangkat yang dikemas dalam bentuk SSP tersebut harus mencerminkan sikap karakter yang diinginkan seperti karakter kreatif dan tanggung jawab. Penilaian hasil belajar yang digunakan untuk mengukur karakter kreatif dan tanggung jawab dalam SSP juga memuat karakter kreatif dan tanggung jawab.

Menurut Kraus International Publications (1992) mengembangkan sebuah "taksonomi Pendidikan Sains"baru yang memperluas pandangan tentang pendidikan sains di luar dua domain (isi dan proses) menjadi lima domain yang dianggap penting untuk setiap kurikulum yang baik. Para pengembang kurikulum dapat menggunakan taksonomi itu sebagai arahan dalam menyusun program baru. Lima domain adalah pengetahuan, proses, kreativitas, sikap dan aplikasi. Domain yang digunakan sebagai dasar dalam pengembangan perangkat SSP dalam penelitian ini adalah mengenai domain kreativitas.

Banyak penelitian dan pengembangan yang telah dilakukan pada pengembangan kemampuan para siswa dalam domain kreativitas akan tetapi sedikit yang direncanakan untuk dipadukan ke dalam program sains (Prasetyo, 1998).

PCK yang sudah digunakan oleh para guru selama ini belum menekankan dan memuat makna pendidikan karakter baru sebatas pada transfer konten materi dan bagaimana peserta didik dapat menguasai materi pembelajaran. Muatan karakter yang ditekankan belum tersurat dalam langkah-langkah pembelajaran yang dilakukan. Baru sebatas tersirat dalam penentuan proses penilaian. Peserta didik selama ini mendapatkan pendidikan karakter hanya pada pelajaran Agama dan PKn disekolah.

Jika semua mata pelajaran menerapkan dan mengintegrasikan pendidikan karakter ke pada peserta didik maka akan membentuk kebiasaan baik (habit) sehingga sikap peserta didik akan mencapai optmal dan mutu hasil belajar terutama pembentukan karakter sesuai dengan tujuan pendidkan nasional.

SSP yang akan dibuat di harapkan dapat mengintegrasikan penddikan karakter ke semua aspek dengan perpaduan antara konten dan pendagogi karakter yang diinginkan. Harapan yang di dapat jika SSP ini dibuat maka guru dapat mengacu dan menjadikan SSP sebagai rambu-rambu dalam proses pembelajaran yang berlangsung sehingga pendidikan karakter akan terus dilakukan selama proses pembelajaran berlangsung.

Profil karakter diharapkan dapat menghasilkan pemimpin yang tangguh, berbobot, dan 
berdedikasi tinggi demi kemajuan masyarakat, bangsa, negara, dan individu sendiri. Sehingga generasi penerus bangsa dapat menjadi generasi yang menuju ke arah yang lebih positif karakternya.

Sampai saat ini penelitian mengenai pengintegrasian pembelajaran karakter sudah dilakukan tapi masih terbatas pada tingkat pendidikan SD dan SMP. Penelitian pengintegrasian karakter pada pembelajaran biologi baru sebatas pada karakter tertentu di tingkat pendidikan SMA yang dilakukan oleh Lusyana (2012), mengenai domain pengetahuan untuk meningkatkan karakter tanggung jawab dan domain sikap untuk meningkatkan karakter kritis dan peduli lingkungan oleh Suciyati (2012); Zubaidah (2012), mengenai karakter aplikasi untuk meningkatkan sikap mandiri. Penelitian tentang pengintegrasian karakter domain kreativita dan tanggung jawab pada materi zat makanan tambahan ke dalam mata pelajaran Biologi pada tingkat pendidikan SMA belum pernah dilakukan.

Berdasarkan uraian tersebut, peneliti termotivasi untuk mengintegrasikan nilai-nilai karakter dalam mata pelajaran Biologi melalui pengembangkan SSP Biologi berbasis domain kreativitas untuk mengembangkan dan meningkatkan karakter kreatif dan tanggung jawab serta prestasi hasil belajar siswa di SMA khususnya siswa kelas XI IPA.

Tujuan penelitian ini adalah, (1) Menghasilkan SSP Biologi berbasis domain kreativitas yang valid, praktis dan efektif dalam mengembangkan karakter kreatif dan tanggung jawab pada diri siswa; (2) Meningkatkan kualitas produk SSP Biologi berbasis domain kreativitas dalam mengembangkan karakter kreatif dan tanggung jawab pada diri siswa; (3) Mengetahui produk SSP Biologi berbasis domain kreativitas yang dihasilkan mampu meningkatkan karakter kreatif dan tanggung jawab serta hasil belajar siswa.

Adapun manfaat penelitian ini adalah (1) Sebagai alternatif SSP yang bisa digunakan oleh guru SMA bidang studi Biologi dalam meningkatkan kegiatan pembelajaran berbasis karakter kreatif dan tanggung jawab; (2) Membentuk siswa yang memahami hakekat sains (Biologi) sebagai sikap, proses dan aplikasi agar mereka memiliki bekal pengetahuan konsep dan keterampilan tingkat tinggi yang dapat diterapkan sebagai life skill yang memiliki jiwa karakter kreatif dan tanggung jawab.

\section{METODE}

Jenis penelitian yang digunakan adalah penelitian dan pengembangan $(R$ and $D)$ (Borg $\&$ Gall, 1983, p. 772). Penelitian dan pengembangan ini terdiri atas: Pendahuluan, perencanaan, melakukan uji pendahuluan di lapangan, revisi terhadap produk, melakukan uji di lapangan dan revisi produk operasional. Produk pengembangan dalam penelitian ini berupa perangkat pembelajaran subjek spesifik pedagogis (SSP) Biologi berbasis domain kreativitas untuk mengembangkan karakter kreatif dan tanggung jawab terdiri atas silabus, rencana pelaksanaan pembelajaran (RPP), materi, lembar kerja siswa (LKS), dan lembar penilaian siswa yang disesuaikan dengan Standar Kompetensi siswa SMA yang terintegrasi pendidikan karakter kreatif dan tanggung jawab.

Waktu penelitian dilakukan pada semester 1 tahun ajaran 2012/2013. Tempat penelitian adalah SMA Negeri 8 Yogyakarta, Jalan Sidobali Nomor 1 Kota Yogyakarta. Subjek penelitian yang digunakan terdiri atas kelas control (KK) dan kelas perlakuan (KT). Penentuan sampel diperoleh secara stratifield proportional random sampling terdiri atas pretest-postest group design.

Tabel 1. Desain Eksperimen Pretest-Posttest Group Design

\begin{tabular}{cccc}
\hline Group & Pretest & Perlakuan & Postest \\
\hline KK & P1 & Xa & P2 \\
KT & P1 & Xb & P2 \\
\hline & & \multicolumn{2}{c}{ (Sugiyono, 2006, p. 112) }
\end{tabular}

Keterangan:

KT : Kelas treatmen

KK : Kelas kontrol

P1 : Penilaian sebelum pembelajaran (posttest)

P2 : Penilaian setelah pembelajaran (posttest)

$\mathrm{Xa}$ : Pembelajaran Biologi menggunakan perangkat PCK

$\mathrm{Xb}$ : Pembelajaran Biologi menggunakan produk SSP

\section{Teknik Analisis Data}

Analisis Telaah Perangkat SSP

Tabel 2. Konversi Skor Menjadi Nilai Skala Empat

\begin{tabular}{lc}
\hline \multicolumn{1}{c}{ Skor Siswa } & Kriteria \\
\hline $\mathrm{Mi}+1,5 \mathrm{SDi} \leq \mathrm{X} \leq \mathrm{Mi}+3,0 \mathrm{Sdi}$ & Amat Baik \\
$\mathrm{Mi}+$ 0 SDi $\leq \mathrm{X}<\mathrm{Mi}+1,5 \mathrm{Sdi}$ & Baik \\
$\mathrm{Mi}-1,5 \mathrm{SDi} \leq \mathrm{X}<\mathrm{Mi}+3$ 0 Sdi & Cukup \\
$\mathrm{Mi}-3 \mathrm{SDi} \leq \mathrm{X}<\mathrm{Mi}-1,5 \mathrm{Sdi}$ & kurang \\
\hline
\end{tabular}


Keterangan:

$\mathrm{X}$ : Skor aktual

Mi : $1 \frac{1}{2}$ (skor tertinggi ideal + skor terendah ideal)

SDi : 1/6 (Skor tertinggi ideal-skor terendah ideal)

Skor tertinggi ideal: $\Sigma$ butir kriteria x skor tertinggi

Skor terendah ideal: $\Sigma$ butir kriteria x skor terendah

Analisis Keterlaksanaan Pembelajaran

Reliabilitas lembar observasi keterlaksanaan RPP menggunakan rumus sebagai berikut:

$\mathrm{R}=\left(1-\frac{A-B}{A+B}\right) \times 100 \%$

Keterangan:

$\mathrm{R}$ : Reliabilitas instrumen

A : Skor yang lebih tinggi dari pengamat

B : Skor yang lebih rendah dari pengamat

Analisis Data Tes Hasil Belajar Siswa

Nilai yang diperoleh kemudian dihitung dengan menggunakan rumus sebagai berikut (Menteri Pendidikan Nasional, 2006):

Skor perolehan

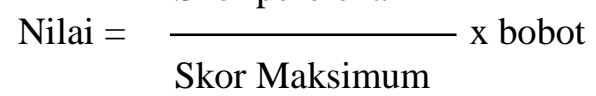

Keterangan:

Nilai : Nilai yang diperoleh siswa

Skor Perolehan : Skor yang diperoleh siswa

Skor maksimum: Skor total

Bobot : Bobot sebesar 100

Analisis Perbedaan Hasil Belajar dan

Pengembangan Karakter KK dan KT

Penggunaan gain standar rumus dari (Meltzer, 2002, p. 3) adalah:

(Skor posttest - Skor pretest)

Gain Standar $=$

(Skor maksimum - Skor pretest)

Selanjutnya dilakukan uji-t dengan menggunakan SPSS.

\section{HASIL DAN PEMBAHASAN}

Penelitian ini akan menghasilkan produk akhir perangkat SSP Biologi domain kreativitas untuk meningkatkan karakter kreativitas dan tanggung jawab pada siswa. Berdasarkan uji kemampuan awal karakter kreatif nilai $\mathrm{F}$ hitung sebesar 0,450 dengan nilai $\alpha$ sebesar 0,505. Kenyataan ini menunjukan bahwa $\mathrm{F}$ hitung > 0,05 maka kemampuan awal karakter kreatif antara kelas kontrol dan treatmen sama. Pada uji beda rerata kreatif awal antara kontrol dan treatmen tidak ada perbedaan yang signifikan $(\mathrm{t}=-1,311 ; \alpha=0,195)$.

Pada uji kemampuan awal karakter tanggung jawab dimana $\mathrm{F}$ hitung sebesar 1,533 dengan nilai $\alpha$ sebesar 0,221 . Kemampuan awal karakter tanggung jawab kelas kontrol dan treatmen sama karena $\mathrm{F}$ hitung lebih besar dari 0,05. Pada uji beda varian karakter tanggung jawab menunjukan tidak ada beda rerata kemampuan awal karakter tanggung jawab antara kelas kontrol dan kelas treatmen ( $\mathrm{t}=-1,239 ; \alpha=0,220)$.

Uji kemampuan awal kognitif didapat nilai $\mathrm{F}$ hitung sebesar 0,651 dengan nilai $\alpha$ sebesar 0,423. Kemampuan awal varian kelas kontrol dan treatmen adalah sama karena $\mathrm{F}$ hitung lebih besar dari 0,05. Pada uji beda rerata $-0,723$ dengan nilai $\alpha=0,473$ menunjukan tidak ada beda rerata kemapuan kognitif kelas treatmen dan kontrol. Berdasarkan analisis tersebut menunjukkan bahwa kelas XI IPA3 dan IPA5 memiliki kemampuan varian yang sama serta tidak ada perbedaan pada uji beda rerata.

Perlakuan ni menggunakan perangkat PCK biasa yang dilakukan oleh guru dalam melakukan proses pembelajaran. Perlakuan selanjutnya perlakuan dengan menggunakan produk SSP yang sudah di validasi terdiri atas silabus, RPP, LKS, Respon siswa, angket karakter dan hasil belajar. Hasil yang diperoleh adalah sebagai berikut

\section{Analisis Keterlaksanaan RPP}

Proses pembelajaran yang dlakukan dengan menggunakan model PBL dan metode inkuiri. Model PBL digunakan untuk merangsang berpikir lebih kreatif dan bertanggung jawab dengan diberikan permasalahan yang terjadi di lingkungan sekitar siswa sehingga siswa lebih tanggap dan memiliki rasa tanggung jawab.

Data keterlaksanaan pembelajaran diperoleh dari observer selama proses pembelajaran berlangsung. Hasil pengamatan tersebut digunakan untuk pengembangan SSP Biologi domain kreativitas untuk meningkatkan karakter kreatif dan tanggung jawab pada siswa.

Skor rerata penilaian pada pertemuan pertama sebesar 4,06; pertemuan kedua sebesar 4,19 dan pertemuan ketiga sebesar 4,06 dan termasuk kategori sangat baik. Pertemuan kedua lebih tinggi dibandingkan pertemuan pertama dan ketiga. Hal tersebut dimungkinkan pada pertemuan pertama siswa masih beradaptasi dengan pembelajaran yang akan dilakukan. Sedangkan pertemuan selanjutnya siswa sudah mulai beradaptasi dengan proses pembelajaran yang menggunakan SSP. Nilai R yang diperoleh masing-masing pertemuan $\mathrm{R} 1=94,78$; $\mathrm{R} 2=$ 96,58; R3 = 98,38 (Gambar 1). Berdasarkan 
nilai $\mathrm{R}$ tersebut maka instrumen termasuk kategori baik. Nilai total rerata alpha Cronbach's adalah 0,887 .

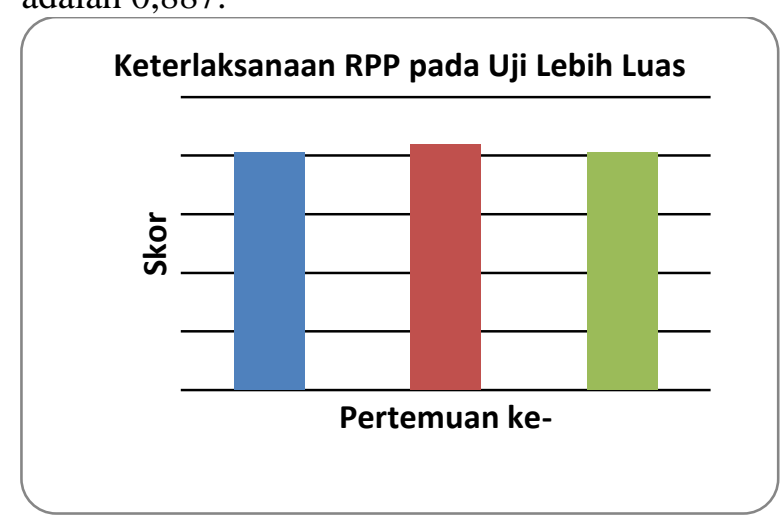

Gambar 1. Grafik Keterlaksanaan RPP

Berdasarkan dari gambar 1 keterlaksanaan RPP dapat tercapai. SPP yang dibuat dapat tercermin dalam keterlaksanaan RPP

\section{Analisis Lembar Angket dan Observasi Ketercapaian Peningkatan Karakter}

Data hasil angket dan observasi ketercapaian peningkatan karakter seperti pada Tabel 3.

Tabel 3. Data Skor Ketercapaian Peningkatan Karakter Kreatif

\begin{tabular}{lccl}
\hline \multirow{2}{*}{\multicolumn{1}{c}{ Data }} & \multicolumn{2}{c}{ Skor Karakter } & \multirow{2}{*}{ Kategori } \\
\cline { 2 - 3 } & KK & KT & \\
\hline Skor tertinggi & 72,0 & 82,0 & Amat baik \\
Skor terendah & 65,0 & 74,0 & Baik \\
Rerata & 69,23 & 78,03 & Cukup \\
Standar deviasi & 1,99 & 1,55 & Kurang \\
\hline
\end{tabular}

Berdasarkan Tabel 3 terlihat bahwa skor karakter kreatif tertinggi pada kelas treatmen sebesar 82,0 dan skor terendah sebesar 74,0 sedangkan skor tertinggi pada kelas kontrol sebesar 72,5 dan skor terendah sebesar 65,0. Rerata nilai skor tertinggi pada kelas treatmen 78,03 terendah kelas kontrol 69,23. Berdasarkan konversi dengan skala empat, semua skor tersebut berada pada interval $60<x<78$, dengan katagori baik.

Tabel 4. Skor Ketercapaian Peningkatan Karakter Tanggung Jawab

\begin{tabular}{lccl}
\hline \multirow{2}{*}{\multicolumn{1}{c}{ Skor }} & \multicolumn{2}{c}{ Skor Karakter } & \multirow{2}{*}{ Kategori } \\
\cline { 2 - 3 } & KK & KT & \\
\hline Skor tertinggi & 30,0 & 35,0 & Amat baik \\
Skor terendah & 25,0 & 28,0 & Baik \\
Rerata & 27,03 & 31,43 & Cukup \\
Standar deviasi & 1,44 & 2,08 & Kurang \\
\hline
\end{tabular}

Pengambilan data pada karakter tanggung jawab sama dengan pengukuran peningkatan karakter kreatif. Skor ketercapaian peningkatan karakter dapat dilihat pada Tabel 4.

Berdasarkan Tabel 4 terlihat bahwa skor tertinggi karakter tanggung jawab pada kelas treatmen sebesar 35,0 dan skor terendah sebesar 28,0 sedangkan skor tertinggi kelas kontrol sebesar 30,0 dan skor terendah sebesar 25,0. Berdasarkan koversi skala empat, sebanyak 26 siswa pada kelas kontrol termasuk kategori baik dan 4 siswa termasuk kategori cukup. Hal ini berbeda dengan kelas treatmen, dimana sebanyak 28 siswa termasuk kategori baik dan 2 siswa termasuk kategori amat baik., hanya frekuensi yang harus ditambah dan dikembangkan sehingga tertanam rasa tanggung jawab yang tinggi.

\section{Ketercapaian Hasil Belajar Siswa Domain Kreativitas}

Ketercapaian hasil belajar siswa domain kreativitas diperoleh dari hasil pengukuran pretes dan posttest yang dilakukan pada uji coba lebih luas. Hal ini dilakukan dengan tujuan untuk melihat seberapa besar pengaruh hasil belajar terhadap perlakuan yang diberikan terhadap peningkatan skor hasil belajar siswa. Teknik yang digunakan untuk melihat perbedaan tersebut analisis gain standar. Skor ketercapaian hasil belajar siswa domain kreativitas dapat dilihat pada Tabel 5.

Tabel 5. Ketercapaian Hasil Belajar Siswa

\begin{tabular}{lcccc}
\hline \multirow{2}{*}{ Skor } & \multicolumn{4}{c}{ Nilai Hasil Belajar } \\
\cline { 2 - 5 } & \multicolumn{2}{c}{ Kelas Kontrol } & \multicolumn{3}{c}{ Kelas treatmen } \\
\cline { 2 - 5 } & Pretest & Posttest & Pretest & Posttest \\
\hline Skor tertinggi & 79,60 & 87,50 & 78,90 & 93,33 \\
Skor terendah & 62,00 & 69,65 & 62,00 & 77,33 \\
Rerata & 71,68 & 77,93 & 72,69 & 85,79 \\
Standar Deviasi & 5,51 & 4,26 & 5,33 & 4,64 \\
\hline
\end{tabular}

Berdasarkan pada Tabel 5, nilai pretest tertinggi yang diperoleh kelas kontrol sebesar 79,60 dan nilai terendah sebesar 62,00 dengan rerata sebesar 71,68 . Nilai pretest tertinggi pada kelas treatmen sebesar 78,90 dan nilai terendah sebesar 62,00 dengan rerata sebesar 72,89.

Rerata nilai posttest tertinggi kelas treatmen sebesar 85,79 sedangkan kelas kontrol tanpa menggunakan SSP mendapat nilai sebesar 77,93. Nilai gain standar pada kelas kontrol sebesar 0,39 sedangkan kelas treatmen sebesar 0,77 . Nilai gain standar pada posisi 0,77 menandakan bahwa peningkatan hasil belajar berada pada tingkat level tinggi yaitu diatas $\mathrm{g}>0,7$.

Tingkat ketuntasan hasil belajar domain kreativitas pada proses pembelajaran Biologi 
yang berlangsung di kedua kelas dapat dilihat pada Tabel 6. Ketuntasan belajar dilihat dari hasil belajar yang diperoleh dari siswa mengerjakan ujian. Nilai yang diperoleh disesuaikan dengan nilai KKM kelas XI IPA untuk bidang Biologi (nilai KKM Biologi = 75). Jika kurang memenuhi maka dianggap belum berhasil dalam proses pembelajaran.

Tabel 6. Ketuntasan Hasil Belajar Domain Kreativitas

\begin{tabular}{lcccc}
\hline \multirow{2}{*}{ Kriteria } & \multicolumn{4}{c}{ Jumlah Siswa } \\
\cline { 2 - 5 } & KK & Prosentase & KT & Prosentase \\
\hline Tuntas & 24 & $80 \%$ & 30 & $100 \%$ \\
Tidak & 6 & $20 \%$ & 0 & $0 \%$ \\
Tuntas & 6 & & 0 & \\
\hline
\end{tabular}

Berdasarkan Tabel 6 terlihat bahwa kelas kontrol yang tuntas sebanyak 24 siswa $(80 \%)$ sedangkan yang tidak tuntas 6 siswa (20\%). Tingkat ketercapaian proses pembelajaran baik (reliabilitas tinggi), jika dapat mencapai nilai $>75 \%$. Berbeda dengan kelas treatmen yang memilki indeks tuntas 30 siswa dengan ketercapaian $100 \%$. Hal ini dapat dikatakan bahwa perangkat SSP yang digunakan mampu membantu siswa dalam menyerap materi pembelajaran yang dilaksanakan.

\section{Respon Siswa terhadap Perangkat SSP Biologi Domain kreativitas}

Skor respon siswa pada kegiatan pembelajaran dengan menggunakan perangkat SSP terhadap materi ajar, LKS dan proses pembelajaran sebagai berikut: skor total respon siswa terhadap materi ajar sebesar 48,81 dengan kategori sangat setuju, skor total respon siswa terhadap LKS sebesar 30,17 dengan kategori sangat setuju dan skor total respon siswa terhadap proses pembelajaran sebesar 43,57 dengan kategori sangat setuju dengan proses pembelajaran yang berlangsung. Dengan demikian baik materi ajar, LKS dan proses pembelajaran siswa sangat setuju. Maka perangkat SSP yang dibuat sudah termasuk kategori yang telah diinginkan siswa untuk belajar.

\section{Analisis Peningkatan Karakter dan Tes Hasil Belajar Siswa}

Analisis peningkatan karakter dan tes hasil belajar dilakuan dengan menggunakan uji normalitas dan uji homogenitas. Uji Normalitas dipenuhi jika hasil uji tidak signifikan untuk taraf signifikansi tertentu. Hasil uji pra-syarat secara lengkap dapat dilihat pada Tabel 7.
Tabel 7. Hasil Uji Normalitas

\begin{tabular}{|c|c|c|}
\hline Data & Sig.(p) & Keterangan \\
\hline Karakter kreativitas & 0,103 & $\begin{array}{c}\text { Distribusi } \\
\text { normal }\end{array}$ \\
\hline Karakter tanggung Jawab & 0,074 & $\begin{array}{c}\text { Distribusi } \\
\text { normal }\end{array}$ \\
\hline $\begin{array}{l}\text { Gain Standar Nilai Hasil } \\
\text { Belajar }\end{array}$ & 0,581 & $\begin{array}{c}\text { Distribusi } \\
\text { normal }\end{array}$ \\
\hline
\end{tabular}

Berdasarkan Tabel 7 terlihat bahwa harga signifikansi karakter kreativitas 0,103 , tanggung jawab 0,074 dan gain standar 0,581 nilai tersebut jauh lebih besar dari harga sebesar 0,05. Pada peningkatan hasil belajar beda gain standar bernilai $\mathrm{g}<0,7$ menyatakan hasil belajar mengalami peningkatan baik dari sebelumnya.

Uji homogenitas digunakan untuk melihat apakah sampel yang ada homogen atau tidak. Hasil uji homogenitas dapat dilihat pada Tabel 8.

Tabel 8. Hasil Uji Homogenitas

\begin{tabular}{llc}
\hline \multicolumn{1}{c}{ Data } & \multicolumn{1}{c}{ Sig.(p) } & Keterangan \\
\hline $\begin{array}{l}\text { Karakter kreativitas } \\
\text { 0,340 }\end{array}$ & 0,659 & Homogen \\
$\begin{array}{l}\text { Gain Standar Nilai Hasil } \\
\text { Belajar }\end{array}$ & Homogen & \\
\hline
\end{tabular}

Berdasarkan Tabel 8 terlihat bahwa pada hasil uji homogenitas harga signifikansi dari data karakter kreativitas, tanggung jawab dan gain standar jauh lebih besar dari 0,05, sampel berasal dari populasi yang homogen.

Hasil analisis menunjukan bahwa sampel berdistribusi normal dan bersifat homogen maka uji prasyarat untuk melakukan uji $\mathrm{t}$ (independent sample $t$-test) dapat terpenuhi. uji t dilakukan dengan menggunakan bantuan komputer program SPSS.

\section{Peningkatan Karakter Kreativitas}

Pengujian hipotesis dilakukan pada data skor yang diperoleh dari rerata skor angket dan observasi karakter kreatif dan tanggung jawab. Hasil analisis uji beda peningkatan karakter kreatif dapat dilihat pada Tabel 9.

Tabel 9. Uji Beda Peningkatan Karakter Kreatif

\begin{tabular}{ccccc}
\hline Kelas & Rerata & t & Sig $(\mathbf{p})$ & Keterangan \\
\hline KK & 69,23 & \multirow{2}{*}{$-17,66$} & \multirow{2}{*}{0,000} & \multirow{2}{*}{$\mathrm{H}_{0}$ ditolak } \\
KT & 78,63 & & & \\
\hline
\end{tabular}

Berdasarkan Tabel 9 harga $t=-17,665$ dengan taraf signifikansi 0 . Hal ini berarti bahwa ada perbedaan yang signifikan pada peningkatan ketercapaian karakter kreatif antara kelas 
dengan perangkat biasa dan yang menggunakan SSP Biologi domain kreativitas.

\section{Peningkatan Karakter Tanggung Jawab}

Pengujian hipotesis dapat diperoleh berdasarkan hasil dari analisis rerata skor angket dan observasi setelah pembelajaran berlangsung. Hasil uji beda ketercapaian peningkatan karakter tanggung jawab dapat dilihat Tabel 10.

Tabel 10. Uji Beda Peningkatan Karakter Tanggung Jawab

\begin{tabular}{ccccc}
\hline Kelas & Rerata & t & Kondisi & Keterangan \\
\hline KK & 27,03 & & & \\
KT & 31,43 & $-12,46$ & $\mathrm{P}<0,05$ & $\mathrm{H}_{0}$ ditolak \\
\hline
\end{tabular}

Berdasarkan Tabel 10 harga $\mathrm{t}=-12,469$, berarti bahwa ada perbedaan yang signifikan pada peningkatan ketercapaian karakter tanggung jawab antara kelas dengan perangkat biasa dan yang menggunakan SSP Biologi domain kreativitas.

Berdasarkan analisis tersebut maka dapat disimpulkan bahwa ada perbedaan yang signifikan terhadap hasil peningkatan karakter kreativitas dan tanggung jawab antara siswa yang mengikuti pembelajaran SSP Biologi berbasis domain kreativitas dengan perangkat pembelajaran yang biasa digunakan (PCK).

Ketercapaian peningkatan karakter kreatif terlihat pada siswa yang menggunakan perangkat SSP Biologi domain kreativitas. Penggunaan perangkat pembelajaran adalah alat yang paling baik dalam proses pembelajaran karena dapat mengukur dan mengarahkan sistem pembelajaran terhadap apa yang pengajar inginkan terhadap peserta didik. Pengajaran kreatif dapat digambarkan ke dalam dua bentuk yakni mengajar dengan kreatif dan mengajar untuk kreatif. Mengajar dengan kreatif digambarkan ketika guru menggunakan pendekatan imajinatif untuk pelajaran menjadi lebih menarik, melibatkan, menggairahkan dan efektif. Mengajar karena kreativitas cara terbaik digambarkan ketika menggunakan wujud-wujud tentang pengajaran yang diharapkan untuk mengembangkan pemikiran kreatif dan perilaku peserta didik.

Berdasarkan masalah yang dikemukakan berharap siswa mampu mengembangkan ide kreatif untuk menangani masalah tersebut sehingga kreativitas siswa dapat muncul dan terasah menjadi suatu kebiasaan.

Sikap dan perilaku tanggung jawab merupakan sikap yang berani menanggung segala akibat dari perbuatan yang telah dilakukannya. Orang yang bertanggung jawab sesungguhnya telah memiliki modal yang sangat berharga untuk menjadi orang yang adil. Tanggung jawab akan tumbuh jika anak memiliki visi yang kuat.

Nilai karakter tanggung jawab pada kelas treatmen lebih tinggi dibandingkan kelas kontrol. Dimana kelas treatmen adalah kelas yang menggunakan perangkat SSP Biologi domain kreativitas pada karakter tanggung jawab. Siswa untuk memikirkan tanggung jawab sebagai seorang pelajar dalam hal pembagian waktu yang digunakannya. Siswa mempunyai tanggung jawab untuk mengembangkan bakatnya di lingkungan juga sebagai pelajar di sekolah yang dituntut untuk belajar dan mengerjakan tugas.

Nilai tanggung jawab di sekolah dapat dilakukan melalui permainan atau tugas-tugas yang menggunakan alat, seperti eksperimen dengan menggunakan bahan pengawet alami sebagai bahan pengawet pada ikan. Hal ini dapat menjadi sarana untuk memperkenalkan dan melatih tanggung jawab pada diri anak setelah praktikum dilakukan untuk menjaga dan memelihara alat yang digunakan kembali seperti semula dengan tertib, mengumpulkan laporan hasil tepat pada waktunya.

Pada kelas treatmen menggunakan SSP Biologi domain kreativitas dengan menanamkan karakter kreatif dan tanggung jawab. Pembelajaran yang didesain dengan menggunakan model pembelajaran PBL, sedangkan untuk mencapai tujuan pembelajaran karakter yang ditanamkan dengan menggunakan metode diskusi tanya jawab dan ekperimen dengan strategi inquiri terbimbing. Siswa dalam eksperimen diberikan materi-materi yang menyangkut materi pembelajaran mengenai bahan makanan tambahan yang berbahaya bagi kesehatan tubuh, selain itu guru juga memberikan beberapa contoh mengenai bahan makanan tambahan yang beredar dipasaran yang sangat berbahaya. Berdasarkan penelitian yang dilakukan terhadap perbedaan proses pembelajaran yang dilakukan di kelas kontrol dan kelas treatmen maka akan menghasilkan peningkatan karakter terhadap karakter kreatif dan tanggung jawab.

Kelas kontrol tidak menggunakan perangkat yang digunakan dalam pembelajaran SSP Biologi namun menggunakan perangkat yang sesuai dengan RPP yang dibuat oleh guru dalam pembelajaran yang biasa dilakukan dengan tidak menanamkan karakter tanggung jawab. Biasanya hal tersebut dilakukan hanya di lisan tidak tertulis di dalam RPP sehingga biasanya tidak mempunyai patokan untuk menanamkan kebiasaan karakter yang akan ditanamkan ke dalam 
diri siswa agar menjadi terbiasa dalam kehidupan sehari-hari.

Analisis ketercapaian tes hasil belajar menunjukkan bahwa ada perbedaan yang signifikan hasil tes hasil belajar yang mengikuti pembelajaran SSP Biologi domain kreativitas dengan perangkat pembelajaran yang biasa. Hal ini di dasarkan pada proses pembelajaran yang berlangsung di dalam kelas. Perangkat pembelajaran yang digunakan dengan menggunakan SSP Biologi domain kreativitas dengan model pembelajaran PBL dapat untuk meningkatkan karakter kreatif dan tanggung jawab serta tes hasil belajar. Berbeda dengan hasil pada kelas kelas kontrol pada kelas ini proses pembelajaran yang dilakukan tanpa menggunakan perangkat SSP Biologi domain kreativitas.

Proses pembelajaran dengan menggunakan perangkat SSP Biologi domain kreativitas lebih efektif karena selain dapat meningkatkan hassil belajar juga dapat menanamkan kebiasaan karakter kretifitas dan tanggung jawab dalam kehidupan sehari-hari.

\section{SIMPULAN}

Produk pengembangan SSP Biologi berbasis domain kreativitas dalam perangkat pembelajaran dapat mengembangkan karakter kreatif dan tanggung jawab pada diri siswa dapat digunakan secara valid praktis dan efektif.

Kualitas SSP Biologi berbasis domain kreativitas dalam mengembangkan karakter kreatif dan tanggung jawab pada diri siswa meningkat dari 69.23 menjadi 78.63

Pengembangan SSP Biologi sebagai perangkat pembelajaran berbasis domain kreativitas yang dihasilkan mampu meningkatkan karakter kreatif dan tanggung jawab serta hasil belajar siswa terdiri atas silabus, RPP, respon siswa, angket karakter dan hasil belajar dengan kategori "baik"

\section{DAFTAR PUSTAKA}

Anonim. (2010). Desain pendidikan karakter. Kementerian Pendidikan Nasional. Jakarta.

Anonim. (2011). Pendidikan karakter di sekolah menengah pertama. Direktorat Pembinaan Sekolah Menengah Pertama. Jakarta.

Bernice, L. (2010). Educating heart and mind strategis for school widw character eeducation. In The 1st International Conference On Character Education. Yogyakarta State University. Yogyakarta:
Universitas Negeri Yogyakarta.

Borg, W. R., \& Gall, M. D. (1983). Educational research: An introduction. New York: Longman.

Koehler, M. J., \& Mishra, P. (2009). What Is technological pedagogical content knowledge? Contemporary Issues in Technology and Teacher Education, 9(1), 60-70. Retrieved from https://citejournal.s3.amazonaws.com/wpcontent/uploads/2016/04/v9i1general1.pdf

Kraus International Publications. (1992). Science curriculum resource handbook: A practical guide for $K-12$ science curriculum. Millwood, NY: Kraus International Publications.

Lickona, T. (1991). Educating for character: how our schools can teach respect and responsibility. Nuw York: Bantam.

Lusyana, D. (2012). Pengembangan subject specific pedagogy (SSP) berbasis domain pengetahuan untuk meningkatkan karakter kerja sama dan karakter tanggung jawab siswa SMA Negeri 8 Yogyakarta. Universitas Negeri Yogyakarta. Retrieved from http://eprints.uny.ac.id/32379/

Meltzer, D. E. (2002). The relationship between mathematics preparation and conceptual learning gains in physics: A possible hidden variable" in diagnostic pretest scores. Am. J. Phys, 70(12), 1259-1268. http://doi.org/10.1119/1.1514215.

Menteri Pendidikan Nasional. Peraturan Menteri Pendidikan Nasional RI nomor 22, tahun 2006, tentang standar isi intuk satuan pendidikan dan menengah, Peraturan Menteri Pendidikan Nasional (2006).

Munandar, S. . U. (2002). Kreativitas dan keberbakatan: Strategi mewujudkan potensi kreatif dan bakat. Jakarta: Gramedia Pustaka Utama. http://doi.org/2002

Munir, A. (2010). Pendidikan karakter: Membangun karakter anak sejak dari rumah. Yogyakarta: Pedagogia.

Musbikin, I. (2006). Mendidik anak kreatif ala Einstein. Yogyakarta: Mitra Pustaka.

Prasetyo, Z. K. (1998). Taksonomi pendìdikan fisika (sains) dalam era pembangunan jangka panjang (PJP) II bangsa indonesia menuju abad-21. Cakrawala Pendidikan.

Seifert, K. (2008). Manajemen pembelajaran \& 


\section{Jurnal Inovasi Pendidikan IPA, 3 (1), 2017 - 21}

Ary Kusmawati

motivasi belajar mengajar. Jakarta: PT Rajagrafindo Persada.

Siswoyo, D. (2007). Ilmu pendidikan. Yogyakarta: UNY Pers.

Suciyati, A. (2012). Pengembangan subject specific pedagogy (SSP) biologi berbasis domain aplikasi untuk meningkatkan karakter mandiri siswa SMA Negeri 8 Yogyakarta. Universitas Negeri Yogyakarta. Retrieved from http://eprints.uny.ac.id/35628/

Sugiyono. (2006). Statistika untuk penelitian. Bandung: CV. Alfabeta.

Usman, M. U. (2006). Menjadi guru profesional. Bandung: Remaja Rosdakarya. http://doi.org/2006

Zubaidah, L. (2012). Pengembangan subject spesicific pedagogy (SSP) biologi berbasis domain sikap untuk meningkatkan karakter kritis dan peduli lingkungan siswa SMA Negeri 8 Yogyakarta. Universitas Negeri Yogyakarta. Retrieved from http://eprints.uny.ac.id/36321/

Zuchdi, D., Agustian, A. G., Hidayat, K., Sardiman, A., Marzuki, M., \& Ode, S. L. (2009). Pendidikan karakter: Grand design dan nilai-nilai target. Yogyakarta: UNY Press.

Zuriah, N. (2011). Pendidikan moral dan budi pekerti dalam perspektif perubahan: Menggagas platfom pendidikan budi pekerti secara kontekstual dan futuristik. Jakarta: Bumi Aksara. http://doi.org/2011 